February 2022

\title{
Reconsidering services marketing as a discipline
}

\author{
Mark S. Rosenbaum \\ Hawaii Pacific University, dr.markrosenbaum@gmail.com \\ German C. Ramirez \\ Universidad Externado de Colombia, german.contreras@uexternado.edu.co
}

Follow this and additional works at: https://digitalcommons.usf.edu/jght

Part of the Hospitality Administration and Management Commons, and the Marketing Commons This View Point is brought to you for free and open access by the M3 Center at the University of South Florida Sarasota-Manatee at Digital Commons @ University of South Florida. It has been accepted for inclusion in Journal of Global Hospitality and Tourism by an authorized editor of Digital Commons @ University of South Florida. For more information, please contact digitalcommons@usf.edu.

\section{Recommended Citation}

Rosenbaum, M. S., \& Ramirez, G. C. (2022). Reconsidering services marketing as a discipline. Journal of Global Hospitality and Tourism, 1(1), 85-87. https://www.doi.org/10.5038/2771-5957.1.1.1005

Corresponding Author

Mark S. Rosenbaum, 900 Fort Street Mall, Suite 600, Honolulu, HI 96813 


\title{
Reconsidering Services Marketing as a Discipline
}

\author{
Mark S. Rosenbaum ${ }^{1}$ and Germán C. Ramírez ${ }^{2}$ \\ College of Business \\ Hawaii Pacific University, United States \\ ${ }^{1}$ dr.markrosenbaum@gmail.com \\ Center for Marketing Studies \\ Universidad Externado de Colombia, Colombia \\ 2german.contreras@uexternado.edu.co
}

\begin{abstract}
This viewpoint suggests that foundational theories and concepts which characterize the services marketing discipline may no longer be valid due to the global pandemic. The authors discuss the impact of the Great Resignation on both consumers and organizations and posit that many consumers now accept lower levels of service offerings and performance. They further question whether organizations will ever return to pre-pandemic service levels. Further, the authors contend that the discipline's focus on employee-customer relationships has now shifted to customertechnology exchanges and that human interactions, in many service exchanges, are diminishing in importance. The authors put forward future research questions.
\end{abstract}

Keywords: pandemic, Great Resignation, service technologies, marketing theory, future of services

\section{Introduction}

Although it is evident that the COVID-19 pandemic has altered global economies and negatively impacted services industries, including hospitality, tourism, and retail, we posit that the changes posed by the pandemic will permanently alter the way services marketing is investigated and practiced. Indeed, the authors of this viewpoint believe that most of the foundational theories and concepts that characterize the services marketing discipline are now invalid because of the global pandemic. As such, both services marketing educators and practitioners employed in service organizations will have to reconsider how they deliver service quality both during and after the turmoil associated with COVID-19.

\section{The Great Resignation Alters Customers' Expectations}

The reasoning behind our contention stems from the fact that in many locales, perceived service quality, which is delivered by human employees, is worsening. In the United States, a phenomenon called the Great Resignation appeared during the COVID-19 crisis as many employees decided to resign from their positions once employers began attempting to return to pre-pandemic operations (Allman, 2021). On the one hand, it is true that the pandemic has provided many people with incentives to retire due their receiving generous federal stimulus money, stock market gains, 
increasing home values, and their having concerns about returning to crowded office spaces. On the other, many younger workers, who often begin their careers as front-line employees in service organizations are also departing the workforce. That is, the Great Resignation is impacting younger-aged workers, as nearly a quarter of workers ages 20 to 34 - some 14 million Americans, are no longer considered part of the U.S. workforce (Bruner, 2021).

As a result of a declining workforce, many service organizations, especially within the U.S. are experiencing difficulties with their ability to return to pre-pandemic service offerings. For example, many hotel organizations are severely curtailing, or even eliminating, their food/beverage and housekeeping services. Similarly, many restaurants have reduced their operating hours or have eliminated in-person dining. Interestingly, the consumer backlash against service organizations regarding these reduced or eliminated services has been minimal, as most consumers justify the changes on the global pandemic and on the employment situation.

The unanswered question concerns whether operations will return to pre-pandemic normal or whether we are experiencing a new normal. We speculate that consumers' expectations regarding many services have been permanently altered by organizational practices and governmental regulations/mandates to such an extent that many consumers will accept lower levels of service. More specifically, we believe that most consumers accept that a return to pre-pandemic marketplace conditions are most likely years away or foregone forever. Further, it is doubtful that service organizations which have curtailed operations, albeit due to challenges due to a declining workforce or as cost-cutting measures, will return their service operations to pre-pandemic levels. By-and-large, service organizations are realizing that with changing customer expectations, they may be able to permanently meet these lowering expectations with a new level of service offerings - a reduced level of offerings compared to those offered pre-pandemic.

\section{Reconsidering Services Marketing as a Discipline}

Not only has the global pandemic altered customers' expectations of acceptable service levels, but also, the pandemic has fundamentally altered the way service researchers, and practitioners, consider service industries. That is, the services marketing discipline, and practices, rest on theories and concepts which assume the importance of in-person exchanges and customer-client relationships. This is not to say that service researchers have not explored topics such as selfservice technologies and robotics in the past; however, the discipline rested on a foundation of thought that was based on customers, including guests, patients, clients, having, or being able to able to access, in-person, employee-client relationships. We believe that this foundation of thought no longer exists.

The pandemic has shifted attention in many service industries from in-person to technological encounters, experiences, and touchpoints. Many consumers who once overlooked organizational technological offerings, are now comfortable using organizational mobile applications and websites for home delivery or curbside pickup. Other service organizations encourage touchless contact between customers and employees, so that, customers are forced to turn to technology to engage in transactions that were once customer-employee human touchpoints. For instance, passengers on United Airlines who plan to purchase food or beverages during the flight must have stored credit card data, as employees no longer process customers' credit cards during flights. Marriott Bonvoy members check-in online and receive their room keys via the mobile applications, 
thus, curtailing front-line employee and customer interactions. Service touchpoints that once afforded customers and employees to engage in social interaction are now silent taps between a customer and an employee's device. Touchpoints that once brought front-line employees into contact with customers and offered opportunities to demonstrate empathy and responsiveness, are now relegated to delivery promptness or silent movements as customers open their automobile trunks to employees to complete service exchanges. Touchpoints that were once opportunities for banter between employees and their customers are now emotionless, even robotic, with the emphasis being on technological prowess rather than on social interaction between, and among, customers and employees.

Service quality has shifted from a focus from in-person to technological offerings. As such, practitioners will be forced to reconsider internal resource allocations and shift dollars from inperson, physical considerations, to technological, virtual considerations. As service organizations increasingly invest in technological advancements, resources will have to shifted internally to fund these advancements. Will hoteliers return to pre-pandemic front-line employment levels? Will airlines relinquish their contactless exchanges and return to human exchanges? Will consumers who were forced to learn how to use retailers' applications suddenly return to in-person transactions post-COVID? We believe that the answer to all these questions is obvious; services have moved from a foundation of thought that rested on employee-customer interactions to organizational technology - customer interactions.

\section{Conclusions}

This viewpoint provides researchers with many opportunities for future explorations. For instance, resarchers may want to explore the following questions:

- How have requirements for touchless contact impacted consumers and will they ever return to touch-intensive contacts?

- As hoteliers embrace and develop mobile technologies, how are customer perceptions of service quality impacted? Is SERVQUAL now TECHQUAL?

- How will service organizations continue to respond to the Great Resignation?

- Has the global pandemic prepared customers/guests/patients for robotic relationships?

- Is relationship marketing dead? Should we have a professional service paradigm that focuses on human relationships while the services paradigm increasingly turns to technology-customer relationships?

We do not have the answers to these questions. However, the fact that we now putting them forward suggests that the time is opportune to reconsider foundational theories that characterzie the services marketing discipline and the way in which services are delivered to consumers and taught in our universities.

\section{References}

Allman, K. (2021). Career matters: The great resignation' sweeping workplaces around the world. LSJ: Law Society of NSW Journal, (81), 46-47.

Bruner, R. (2019, October 29), Young people are leaving their jobs in record numbers-and not going back. Time. https://time.com/6111245/young-workers-quitting/ 